抄 錄

\section{一製 銅—}

$\mathrm{FeO}-\mathrm{Al}_{2} \mathrm{O}_{3} \quad$ 系における起電力の測定 $(\mathbf{1}, 500$ ${ }^{\circ} \mathbf{C}$ ) とX 線的研究 (W. A. Fischer \& A. Hoffmann: Arch. Eisenhüttenw., 26 (1955) 1,43 50

さきに著者の1人子其问破究者によつて考案された固

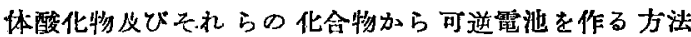
(W. A. Fisher \& Schäfer: 同誌 24 (1953) 307 314）を本系に际び適肌し，多少装置にも改良を加えて， 一層精緇に吟味した。

澌定の方法は，純 $\mathrm{Al}_{2} \mathrm{O}_{3}$ \& $\mathrm{FeO}-\mathrm{Al}_{2} \mathrm{O}_{3}$ 系の粉体を 截頍四錐体状に接触させて招き, 雨端に $\mathrm{Pt}-\mathrm{Pt} \cdot \mathrm{Rh}$ 䓡管 対を捼入して温度制御を計ると共に，2本のPt 線方酒 極となつて真空管管庄計に尊かれることになつている。 すなおち $\Theta \mathrm{Pt}\left|\mathrm{Al}_{2} \mathrm{O}_{3}\right| \mathrm{FeO}+\mathrm{Al}_{2} \mathrm{O}_{3} \mid \mathrm{Pt} \bigoplus$ ，の起電力

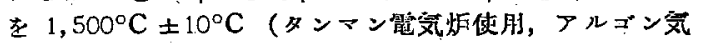
流中）测定した。

実驗後の試料は，A1 き標集物犋としてデバイ・シェ ラー・タメラの対象集注法 (背面反射)及び $1,500^{\circ} \mathrm{C}$ に和ける高温カメラ法を用いて, 諸相の恪子管数を訫算 した.この 2 種のデータから次のよ5に結諭した。

(1) $\mathrm{FeO}$ の格子欠陷, $\mathrm{FeO}-\mathrm{Al}_{2} \mathrm{O}_{3}$ 系に招汀子 $\mathrm{FeO}$

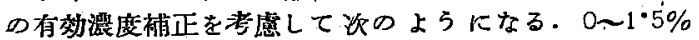

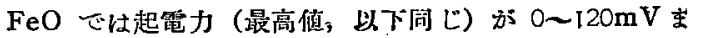
认急激に增 $L, \mathrm{Al}_{2} \mathrm{O}_{3}$ 中一の $\mathrm{FeO}$ の固溶飽和限を示 す. 1.5 48.8\% FeO では起管力が $173 \mathrm{mV}$ までゆる 中かに增加 $\mathrm{L}, \mathrm{FeO}$ で飽和された $\mathrm{Al}_{2} \mathrm{O}_{3}$ とスビネル $\mathrm{FeO} \cdot \mathrm{Al}_{2} \mathrm{O}_{3}$ が共存している. とのスビネルは $\mathrm{Fe}_{3} \mathrm{O}_{4}$ ( ビネル $\mathrm{FeO} \cdot \mathrm{Fe}_{2} \mathrm{O}_{3}$ ) を固溶している. 48:8〜 $50 \% \mathrm{FeO}$ の間で起䉓力が $270 \mathrm{mV}$ まて急激僧し 50 〜 $63 \% \mathrm{FeO}$ ではもは中变化方ない.こっでは $\mathrm{FeO} \cdot \mathrm{Al}_{2} \mathrm{O}_{3}$ と $\mathrm{Al}_{2} \mathrm{O}_{3}$ を溶摪した $\mathrm{FeO}$ (液体) が共存している。

(2) スピネル $\mathrm{FeO} \cdot \mathrm{Al}_{2} \mathrm{O}_{8}$ の格子管数は 8.134

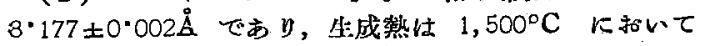
7,500 15,000 cal/Mol である.

(3) スピネル FeO $\cdot \mathrm{Al}_{2} \mathrm{O}_{3}$ 加ら純 $\mathrm{Al}_{2} \mathrm{O}_{3}$ への $\mathrm{Fe}$ の拡散恒数は約 $4 \cdot 10^{-7} \mathrm{~cm}^{2} \cdot \mathrm{sec}^{-1}$ である。(淞下幸雄) (抄録者詰) この答䀫に和ける $\mathrm{Al}_{2} \mathrm{O}_{8}$ 及どメビネルの 境界面の収樎と膨脹 (Kirkendall 効果) については, Naturwissensch., 41 (1954) 7, 162〜163 k籣算枝説 明がある。$$
\text { 一鋳 造一 }
$$

遠心鋳造の一方法 (A.J. Gibbs Smith: Iron \& Steel, 27 (1954), 13, pp. 577 578)

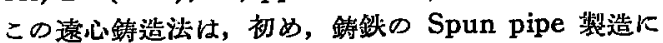
計画さ机たるのである方，最近，合金成分の分離を一店 克服して以来か的り分野方拡張される様になつて今では

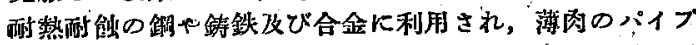
や接続器, 即ビストンリング; ポット,シシダルリング シリンダーライナーペフリングプッシュ等の裴造使
用さ新ている。

遠心鋯造機の回転軸は horizontal なるのと vertical なものとあつて前者は長さが直径の数倍のものに，㷋者， は長さに比へて遖俻の比較的大きなるのに使用されてい 3.

鋳造設倩であるが、モールドを支充て四つのローラー

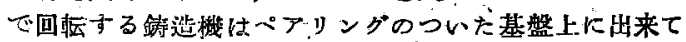
いる.そしてべアリングの間に忙水圧シリシダーが有り モールドの输入及ど抽出を融つている。 二つの固定した

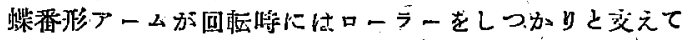

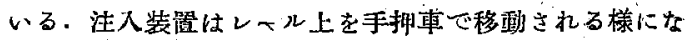

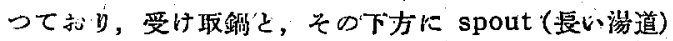
を持つた注入取鍋之から出来ている。モールぼから鋅造

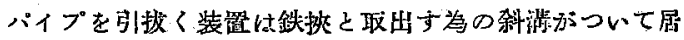
て電贾的に操作出来る様になつている。四つのもールド の容量を有するモールドマガジンには銈梅の中に冾却用 のメヤーブラメトとモールドを予熱するガスバーナーと が装置してある。

次に操業であるが、メタルは最初注入装置の受け取鍋 К入れられ，レール上を走りつょ，既に回耺中のモール ドの端に注入取鍋の spout がとら゙くと受取鈰は自働的 に倾いてッタルは注入取鎝に入り spoutを通つて回枟 中のモールドに流入される。そうすると同㤾に注入取鍋 はレール上を啳退する。注入きれたメタルは逗心力に上 つてモールドの网壁に拡げられパイブが放第に出来上る わけである．注入装置方元の位置にかえる比には渐固し たパイブガ引找台に取出される。この場合の注入温度は

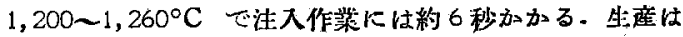
30〜40パイプ/h の割合である.八手は作業の謝節者, 注入手，モールドの交挨手，の三名ですむ. 䉓力は 20

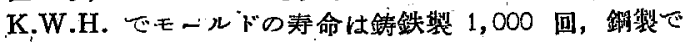
1,500〜2,000回を言わ机ている.

利点は著しく組縺が改善される事でビストンリングな どでは普避の砂型鋳物では見られない特别に細か心パー ライト組織が得られるし义銅の薄肉リングやフランヂで

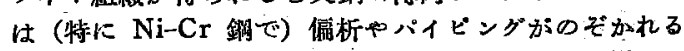

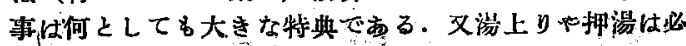

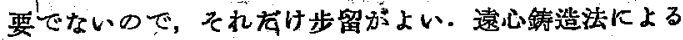
のは，一般の鉜造法に上る留品に比でて同じ材咓のるの です $20 \sim 50 \%$ 程，抗張力が增加していると㝘われてい 了: (谷 昌博)

B-V 真空鋳造法に就て '(R. Sewell：Iron' \& Steel, 28 (1955), 3, p. 111)

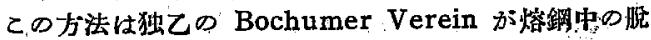

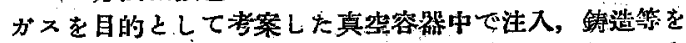
行ら新しいうj湆である.大体， $35 \mathrm{t}$ 位の鋼魄に高さ13ft

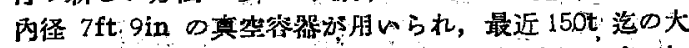
きな銅塊を报ら様になってから漓さ30ft, 丙径 $14 \mathrm{ft} 4 \mathrm{in}$ の真空器加谓いられる様になった。真空ポンブは Ley.

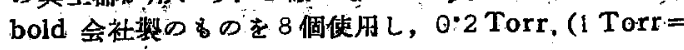




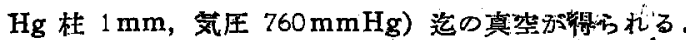

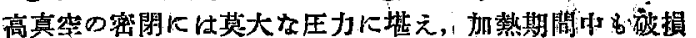
されナ゙，しかも容易に取付け，取はずしが出来るすので 石英硙子の空を通して作業過程㘦よく観察される事を条 件としている.

真空鋳造方法には，取䤾中腃ガス，湯出し中脱ガス， 銓塊鋳造中㹸ガスの三通りがある。

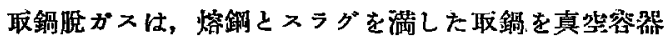
中に入れ，真空ポンブにより脫がスする方法で，石为硝 子を通して観察するとスラグから火山の質出の様に盛え に脱ガスする貌が見られる。湯出し中の膜がスは賣空答 器中に密の取鍋を置き，密閉にはアルミシートを使朋す る: [このマルミは最後に熔けて真空状龍を破る.]泩入

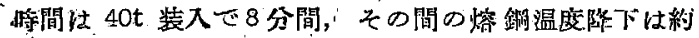

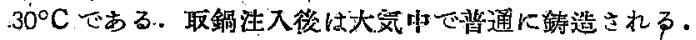
この方法は高合金鑰に適している，之言うのは V， Ti， $\mathrm{Nb}, \mathrm{Al}$ の如き元素の酸化損失を弫止出来るかららあ

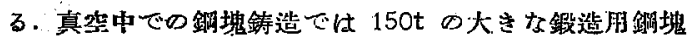
沦鋳造可能となつた。

この $\mathrm{B}-\mathrm{V}$ 法は次の利点がある。

1. 損業者方密閉された容器によつて高热加ら保鄁さ れ，しかる塔銅からの煙霧 (fume) は常にポンプで抽 出されて拓ること.

2. 鋳造中の圧力, ポンブで抽出されるガス量, 熔錒

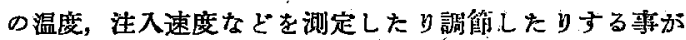
可能なこと.

3. 石英硝子の空から真 空容器内の観察加容易なこ z.

鋳造中に真空容器から抽出されるガスを分析した所， 平均成分として次の吅き結果になつた。[容量\%を示す]

$\mathrm{H}_{2} 20 \%, \mathrm{CO} 45 \%, \mathrm{CO}_{2} 5 \%$; 残 $\mathrm{N}_{2}$

真空下に 100 t銅熄から得たがス試料の分析を見るる 下表の如くである.[重最\%を示す]

\begin{tabular}{|c|c|c|c|c|c|}
\hline 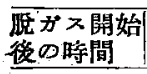 & Torr & $\mathrm{CO}_{2} \%$ & $\mathrm{CO} \%$ & $\mathrm{H}_{2} \%$ & 残\% \\
\hline $\begin{array}{l}10 \text { 分 } \\
25 \text { 分 } \\
60 \text { 分 } \\
240 \text { 分 }\end{array}$ & $\begin{array}{l}2 \\
1 \\
0 \cdot 5 \\
0 \cdot 4\end{array}$ & $\begin{array}{l}1 \cdot 0 \\
4 \cdot 8 \\
5 \cdot 0 \\
1 \cdot 6\end{array}$ & $\begin{array}{l}0 \cdot 8 \\
3 \cdot 0 \\
4 \cdot 4 \\
2 \cdot 2\end{array}$ & $\begin{array}{r}1.2 \\
8.6 \\
9.0 \\
4.4\end{array}$ & $\begin{array}{l}97 \cdot 0 \\
83 \cdot 6 \\
81 \cdot 6 \\
91 \cdot 8\end{array}$ \\
\hline
\end{tabular}

この方法は, パテントになつていて，アメリカ，イン ドその他の国で非常に夙心をよせている゙（谷 昌博）

$$
\text { 一加 I- }
$$

\section{連続鋳造鋼のビレットに起る裂開に就て}

(J. Savage \& W.H. Pritchard: Iron \& Steel, 27 (1954), 14; pp. 649 652, 667 -669)

連続鋳造の磪究者蓶は必ずビレットに起る."裂開”を 問題にする.-Greenidge は連続筹遯ビレット外款の裂 開発生後のたールドの過程を最初に明かにした人であ 了. 彼の㤗は英国鉄銅研究会 [B.I.S.R.A.] 它採り'上げ られ，更に進展されて，現在す储支持されている。

裂開の現象ばモルド壁を通しての藥移換状態を测定 する事に依つて砸明さ杞るもので, この裂開がモールド

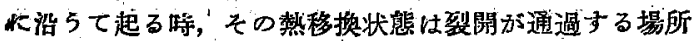
で最高に達する事になる。

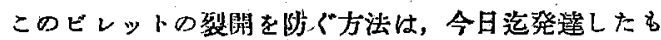
のに二うの方法がある.最初のるのは Junghaus 法で この方法の主なる点はモールドが約 $1 \mathrm{inch}$ 程ビレット と同じ速度で動き，その段階でモールドはビレットが引 加れる速度の約 3 晔の速さでもとの位置に復する矛であ

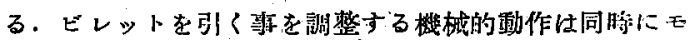
ールドの動きむ調整出来る。

次に，固定したそールドと弱かかれるビレットを断続的 に使㓣する方法は Jacquent に依つて最初に示唆され たもので，基本的には Junghans 法と同じ様なもので ある、この方法は㶧々迅速な加速度が加はる暗は裂開 の起りそらな状態にさらされるが，鬼に㑇連続鋳造過程

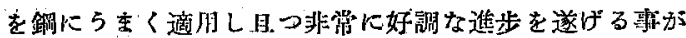
出来たものである.

モールドとビレット閶の應擦がビレットの裂閭には相

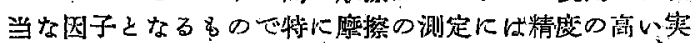

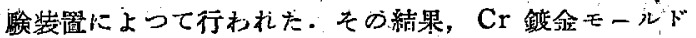

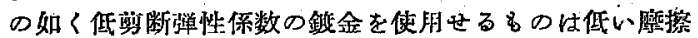
加得られる嵝果となり， Хモ゙ールド测面より規則正しく

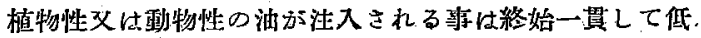
い值の腹擦が期待される㭋台分つた：

連梡鋳喈ビレットの外皮が磨擦に対して耐える茫掁力

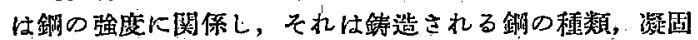
の厚さ，鋼の温度に依存するのである. 要するに，ビレ

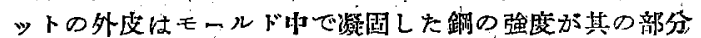
の磨擦力より小さい暗に裂閒を起するので, ビレットの

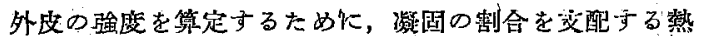
移換現象について测定が行おれ，年の結果炊の式方得ら 礼た。

即ち, $\mathrm{H}=64-8 \sqrt{\mathrm{t}, こ \downarrow て ゙ ~} \mathrm{H}=$ 䓡移换率, $\mathrm{Cal} / \mathrm{cm}^{2}$, sec, $\mathrm{t}=$ 凝固開始加らの暗間 sec.

刃，連続鋳造ビレットの外皮の強度が将間 と其に增加 する事は, 外皮め厚さとモールドに沿5各点の平均温度 加万出来了。

倘，モ心ルドとビレット間の摩擦を测定するために装 置されたスプリング上のモールドを朋いて铸造実験を行 つている內に固定したモールドに比校して”裂開”の

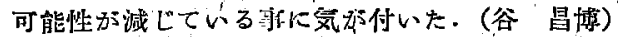

冷間引抜の研究 (I) 鋼に及ほす冷間引抜 の影響 (H. Majors: Trans ASME 77 (1955) 37 $\sim 48$ )

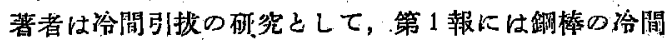
引找，第 2 報には A1 棒の冷間引拔，第 3 報には冾間引 找に於ける摩擦俰数の测定を行つたが，ここに抄稂する

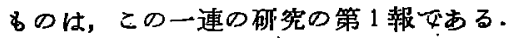

試跧法は外径 1in のSAE 1020 をボードウィン試蹒 柾で連続折返し引拔を行い，引拔方法を Table 1 に示 すょ5に種々変えた場合，機栈的性蜇，残留応力, transition temp.，組織に度任す影湾を調查した。

Table 1. 引拔 方 法

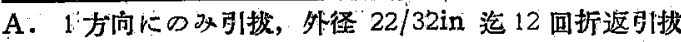
B. 逆方向に交互に引拢，
C. 1 方向にの方拔，外径 $22 / 32$ in 迄 6 回折返司伡.
D. 逆方向に交互に引找, 


\section{实験結果}

a)上に示した引拔方法の影響を次に示す

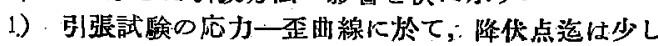

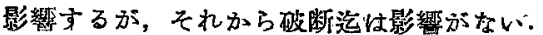

2）ビッカール硬睖には影響がない。

3）表面残留応力には影響方ある.C及びDの方法は Aの方法より表面の残留応力加少い

4）組織に目立つた影唶はない。

b) 加工度の影響は，引張試験の破断の㭙の応力には 影響しない加，歪は断面減少率の增加と共に娍少する。 及最大荷重に於ける在は，诚少率15\%迄は減少するか， それ以上は殆ど変らない。

c) 捻り試駼も行つたが試験数が少なかつた為，満足 な結果は得られかつた。垫り試験では表面の牫留応力の 影響吕大きく; 試験片を切制加工すると降伏点が高くな 了.

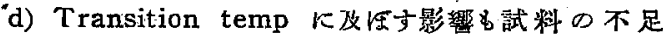
加ら完全な結果は得られかつたが，湓間加工により， transition temp. は上昇するよ5でる。（三角親慶）

\section{不銹鋼線引抜の際の各種造膜㓮の比較}

(A. Pomp: Stahl u. Eisen, 74 (1954) 1325 1334)

線引きの場合，ダイス材料の接触面では，高温，高压 の状㦔となつているので潤滑剂だけで作業を行ら事は困

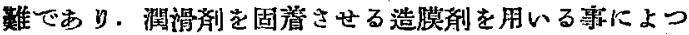
てのみ引找が可能である。

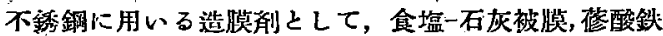
を主体とした Bonder·188 被膜, 酸化膜を变化させた S B 被膛の 3 種に潤滑剂としてステプリン酸カルシュー

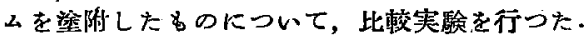

直径 $5 \mathrm{~mm}$ の線材を $2 \cdot 1 \mathrm{~mm}$ 迄連続 6 回の工程によ り， $34 \mathrm{~m} / \mathrm{mn}$ の速度で引拔いた．使用したダイスは， Werth 茂述へたた方法に依り，予め計算した寸法にアル ファ・メーター，ゼット・メーターを用いて測定しなが ら精確に造つた。

一定長さ引找いた後のダイスの抬径量, アルファ・メ

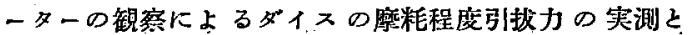
Siebel の理諭式より計算した引拔力との割合から求め た変形工率, プロフィル・メーターの記塗から得た表面

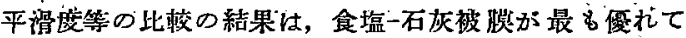
いる. 文; ダイスとの縻擦に上り生ずる表面捬, 引找力, Siebel の式加ら求めた摩擦保数，Anstrengungsgrad 等を比较すると，Bonder 被膜の方がよい結果を示す。 Bonder 被䑏, SB 被膜の場合, 表而平滑度名劣る原因 を著者はこれらの造脱郩は地全と化学的結合をしてい る為と推諭している。

以上の結果を经合すると，Bonder 被点，食塩一石灰 被膜は，殆ど同じ程度であり，いずれの場合をSB 被膜 加一䧽发つている．条任がよりれば，食塩一石灰被膜が

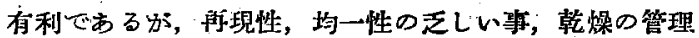

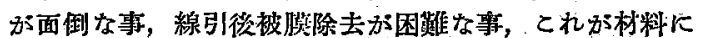
残つていると焼鈍により表面劣化さ生ずる事, ‘製品の ビッティングの原因となる事等の久点があり，䊅局 Bonder 被膜が造膜郕として㑩れていると結言している。

（三角親贯）

\section{0-ton 水圧式鋼板引張稪正機}

(Welding and Metal Fabrication: 23 (1955) 3, pp. 86 87)

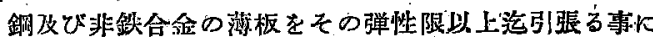
より燆正至行ら方法は实際上金属加工瑟に於し広く用い られて居る。この方法はローラー・レベリングの場合に 比して残留応力が少い為に; 汻板をより平坦にする事为 出来る、双この方法に上的ば表面症を生ずる哥加避けら れると共に，特に低炭素鋼焺針秋の場合には「降伏点伸 ビ」の発生を強力に狮制するので，柎科がプレス或いは 深校り用として用いられる場合には「ストレッチ+ー・ ストレイン」の発止を倣止するのに役立つ.

引張稫正機の主要部分は薄相を均一且强固に保持する 為の「ッカミ」部分と，必要量の引張歪を葫板に与える 為の水圧装置とである゙汃, 斯様な矯正機は Joshua'Bigwood \& Son Ltd. に於て 40 年以上に亘包製造され て和り且々の棐品は全让界に行き亘つて雁る。この長年 の経験は闹社の製品に反映されて抬り，その特徽としし

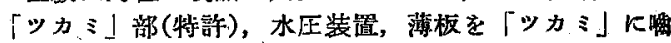

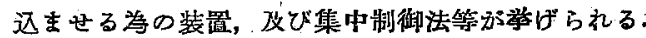
当諭交に於ては, 800-ton の最新式の同怢製引張矯正阵 に就いて，その檴造及び制御法の特徴を紹介して居り， 最㬺にその性能を揭げて居る。その中から主要をるのを 举げて見ると以下の如くである.

最大引張力: $1,792,000 \mathrm{lbs}$,

引張速度: $0 \cdot 039 \mathrm{inch} / \mathrm{sec}$

最小材料長: 59 inch

主動電動機：80 P, 1,440 r.p.m.

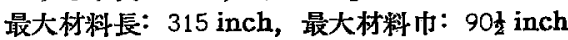

倘この型のものは現在医洲では最大であるが，米国に は800-ton 以上の大容量のもの汃使朋されて居る。

(財前)

\section{珪素鉄単結晶の冷間压延集合粗織}

(P. K. Koh, C. G. Dunn: Journal of Metals, 7 (1955) 2-II, 401

珪素含有量 $3 \cdot 25 \%$ の珪素鉄単結唱を種々の結晶方位

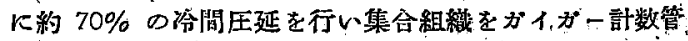
超斩装置で定量的に決定した.

圧延前の結晶方位放，[110] 軸分圧延方向に平行で，压 延面が (111) 面之，(001) 面とのなす銑角內にあ石結晶 面に平行である場合には，泠間圧延によつて殆 ど結晶方 位が変らない。この事は C.S. Barrett 等方 1941 年に 行つた奏跲結果と同じでする.

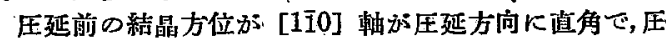
延面が (112) 面己. (001) 面とのなす釷角內にある結晶 面に平行である場合には洛間压延後 (001)-[110]，方位 となり，圧延面が (112) 面之（111）面之のなす舒角内 にある結晶面に平行心五場合には冷間压延後 (111)-

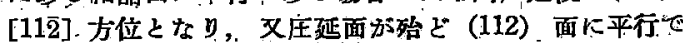
ある場合には压延の際巨視的变形带を生じて結晶方位の 分裂方起 り压延後（001）-[110]；(111)-[112] の二方位 を示亦.

冾間压延中の結奛方位の分敞は Hibbard-Yen の㙨 何学的考察に上つて説明される. 即ち理素铁結晶の觉り 


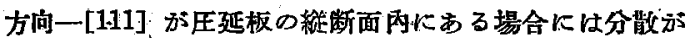
最る小さく，これより外れる程分散が大きくなる。

一次手結晶の傾向は，冷間压延集合組織加 (111) 面 が压延面に平行な場合，例えば（111)-[112]，(111)[ī10] 等の場合には短時間で微細な再結晶粒を生ずるの に対して，冷間圧延集合粗織分 [110] 放圧延方向に平 行な埸会，例えば (001)-[110]，(114)-[110] 等では非 常にゆつくりと大きな程晶粒を生ずる。

、上述の基礎的諸現象は異方性珠素鉄板の契造上重要な 意味を有する。（阿部）

$$
\text { 一性 一質— }
$$

\section{オーステナイトの分解に及ぼす硼素の影響}

(C. R. Simcoe, A. R. Elsea, G. K. Manning: Journal of Metals, 7 (1955) 1-II, 193

$0.22 \mathrm{C}, 0.51 \% \mathrm{Ni}, 0.41 \% \mathrm{Cr}, 0.14 \% \mathrm{Mo}$ の組成 の SAE-8६20 銅及び $0.38 \% 1 \mathrm{C}, 0.50 \% \mathrm{Ni}, 0.34 \%$ $\mathrm{Cr}, 0.14 \%$ Mo の租成の SAE-8635 銅に头々 0.001

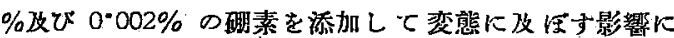
就て砳鞔した。

その結果，磾素を添加すると，フェライト及びでィン イトの核生成度を減ずるために焼入硬化能を増すこと加 明らかになつた。この場会フェライト及びべイナイトの 生長速度には㱛ど影鄉がない。

眀素のためにフェライトみびべィオィトの核生成度が 堿ずるのは，硼素原子吕格子欠降部分に策りそこのエ未 ルギレべルを下げるために核生成が起り䨅くなると教え ら机，又或る程度以上に多くの路素原子少格子久陷部分 に集るとそこのエネルギレデルは逆に高くなつて河び核 生成が起り易くなる。のと考えられる．此の考え方は宽 歐事实をよく説明することがでるる。(阿部)

\section{共析鋼の $\mathbf{A r}_{1}$ 変態に及ぼす張力附加の影響}

(L. S. Birks, E. F. Bailey: Journal of Metals, 7. (1955) 1-II, 179

洪析触の $\mathrm{Ar}_{1}$ 饻態点附近の温度に於ける $\gamma \rightarrow \alpha+\mathrm{Fe}_{3} \mathrm{C}$

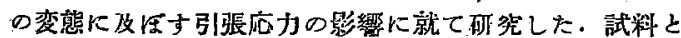
しては； $900^{\circ} \mathrm{C}$ で焼鈍した AISI-1090 踳を用い，裚 態過程は高温 X線腼新スペクトロメーターを朋いて $r$ 相 の (111) 文は (200) 名新線, $\boldsymbol{\alpha}$ 林の (110) 迴析線の 强度柿化を測定した。主な实䟻絬果は炊の如くである。

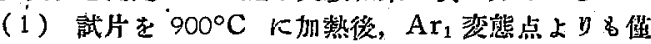
加高以温度 $\left(740^{\circ} \mathrm{C}\right)$ 火保持して $7000 \mathrm{psi}$ の引張荷严

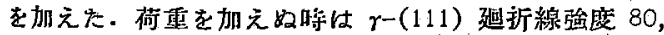
$\gamma$-(200) 佪折線強度 53 であつたのか，菏重を加えると $\gamma$-(111) は 42, $\gamma$-(200) は 76 になつた.

(2) $730^{\circ} \mathrm{C}$ 加 $50^{\circ} \mathrm{F} / \mathrm{mn}$ の速度て $670^{\circ} \mathrm{C}$ 迄沼

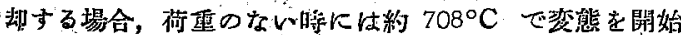
したが, 10700 psi の荷重を加えると約 $718^{\circ} \mathrm{C}$ で掖態 開始するよ5Кなる。とのよらに引張応力は $\mathrm{Ar}_{1}$ 装態 を促進する作用があることが碓認された。(阿部)

オースティト不銹鋼の特性に及ぼす深泠温度加 工の影響 (K. Bungardt, R. Oppenheim u. R. Scherer: Archiv f. d. Eisenhüttenw. 24. (1953) $423 \sim 430$
$\mathrm{Cr}-\mathrm{Ni} ; \mathrm{Cr}-\mathrm{Mo}-\mathrm{Ni}$ \び Cr-Mn オーステナィト不 銹銅常温以下の温度で線引或いは圧延し，加工温度，

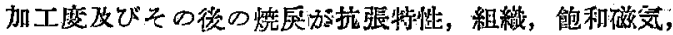
化学的安定性に及ほすす勃果を研究している，加工温度は 一70（液体酸素とアセトンの混合浴）孜び $-180^{\circ}$ (液 体酸素), 線引速度は $1.5 \mathrm{~m} / \mathrm{sec}$, 初めの径 は2・3〜 $4 \mathrm{~mm}$

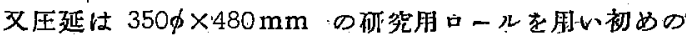
厚さは 2・75〜3 $\mathrm{mm}$. 加工及びその後の焼原に伴5抗張 力, 降伏点の增加は加工洨の大きい程, 又加工温度の低 い程著しい. Si $2 \cdot 54 \%$, Mo 2•15\% を含みオーステナ イトの比輘的不安定な $\mathrm{Cr}-\mathrm{Mo}-\mathrm{Ni}$ 銅では, $-180^{\circ} \mathrm{C}, 60$ $\%$ 線引で抗张力 $210 \mathrm{~kg} / \mathrm{mm}^{2}$, これを $400^{\circ} \mathrm{CK} 24 \mathrm{~h}$

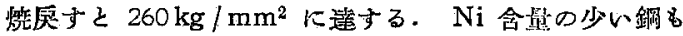
オーステナイトが不安定で加工によつて抗張性質は䓕だ 向上し加工温应の效果も亦顕著でする。 $\mathrm{Nb}, \mathrm{Ta}$ を添 加すると加工初期の硬化を促進し焼厣效果も著しくなる

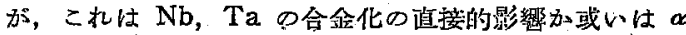
生成量が增すことによる間接的な效果なのか明かでな い. Ti Kついてる同様の勃果が認めら礼る。

$\mathrm{Cr}-\mathrm{Mn}$ 銅は $\mathrm{Cr}-\mathrm{Ni}$ 銅と度く似た踪果を示 L，加工 焼厌の勃果何れる顕著であるが,' $18.52 \% \mathrm{Mn}, 12 \cdot 37 \%$

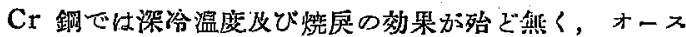
テナイトが極めて安定であることを示している。

一般に深冷温度で加エした埸合は常温に较へて同一抗 張力でる伸びが大きい. 然し絞りは殆ど影響されない。

加工に伴うこの様な抗張性質の著しい向上は磁性の变 化名巨 $\gamma \rightarrow \alpha$ 变態に基因することは明汃である. 常温で 加工してから $-60^{\circ} \mathrm{C}$ 下長特間冷却しても殆ど变驡は起 らないので，深冷温度加工による変態はその低温と加工 との同時作用の結果と楼えられる。

加工材を $400^{\circ} \mathrm{C}$ 附近几㜔厣すと执張力, 降伏点, 硬

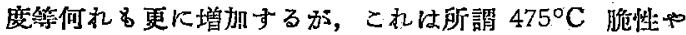

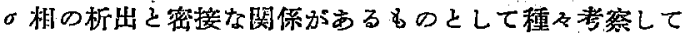
いる. $\sigma$ 相の析出は加工に伴 $5 \alpha$ 相の生成に上つて促 進已礼， Cr-Mo-Ni 銅を $-180^{\circ} \mathrm{C}, 60 \%$ 加工後 $550^{\circ} \mathrm{C}$

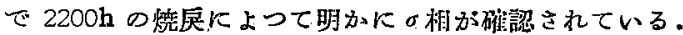

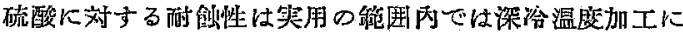
よつて殆ど步化しないととを認めている。（因中良平）

微鉄粉耐久磁石の $(\mathbf{B} \times \mathbf{H}) \max$ に及ぼす他元 素添加の影響 (E. W. Stewart, G. P. Conard II, J. F. Libsch: Journal of Metals: 7 (1955) $1-\mathbb{I}$, 152

C. Kittel, E. C. Stoner, E. P. Wohlfarth, L.

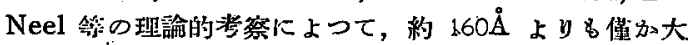
きい程度の微細な鉄粉を固めた材料は落しく大きな抗磁 カを有することが明らかになり，R. S. Dean，C.W. Davis (米国特訢第 2,239, 144 1941. 月 4 月); フラン スの Ugine Co. (英国特許 $590,392 \sim 594,681 \sim 596$, 875)，B. Kopelman 等によつて笑際に製造された。

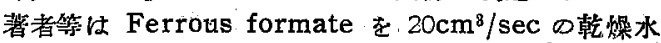
素気流中で加熱逼元して作つた 200 乃至 $1000 \AA$ の大音 さの微制粉材料に $10 \%$ 以下の $\mathrm{Mg}, \mathrm{Cd}, \mathrm{Sn}$ を添加す る場合の磁性の変化に就て㼋究した。 その結果, 之等元 素の添加によつて $(\mathrm{B} \times \mathrm{H}) \max$ を約 1.5 倍に高めるて 
とができた・(阿部)

マルテンサイトの硬さ，その炭素含量に対する 依存性 (Muzaffer Sagisman: Arch f. d. Eisenhitittenw 25 (1954), S. 271

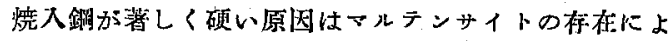
るものと一般に考えられている。そしたこのマルテンサ イトの高硕度估 $\mathrm{E}$. Maurer によれば $\alpha-\mathrm{Fe} へ の \mathrm{C}$ 原 子の強制固溶に基因するとさ秃ている。夷際にCの国溶 によつて $\alpha-\mathrm{Fe}$ が正方晶に歪み, その歪が近似的に C 晴に比例することは Kurdjumow u. Kaminsky 以来 多くの人々によって確認されている。従つてマルデンサ イトの硬さ忧格子の歪に比例し，更にはC皆にも比例す ることが期待されるが, Scheil u. Tonn の砳独は，引

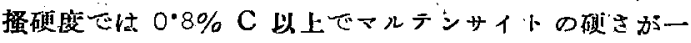
定となり，ブリネル硬度でば $0.8 \%$ 以上て卯つて硬 废が娍少すること示している，この期待と牙实との相 遧は测定方法に基因しているかる知礼ないので著者は、 ルテンサイトのミクロ硬度文湘定した。一逨のC些の高 純炭素嘕主 $1100^{\circ} \mathrm{C}$ 上り焼入し，(A). Vickers 硬度計 (10 kg); (B) Hanemann u. Bernhardt のミ乡硬 度評 $(97 \mathrm{gr})$ 及ど (c) Bergsman のミクロ硕度計(100

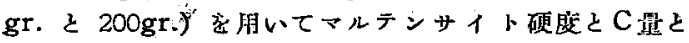
の関倸を求めた（A）ではオーステナイトを合む混合 組䋘の硬度を测ることになり，硬度值最も低く，使用硕 度謰によつて (A)，(B)，(C) の順に硕度值は高くな つているが，C量に詨しては何れも同様の倾向を示し， 0.8〜1.0\% C て最洦硬度が得ら札，こ机上り C 量が増 せ估硬度は却つて低くなる。而して、ルテシサイトのミ

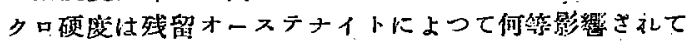
いない。

先の者え方は恐らく正しいと思は机るのて，上の实臉

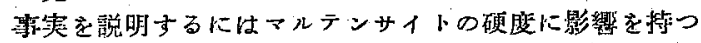

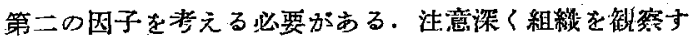

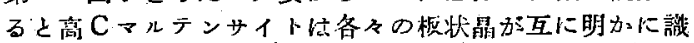

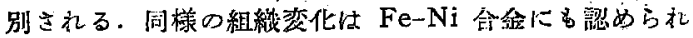
Scheil は $\mathrm{Ni} の$ 多少によつて翌態桡满が舆なり，低 $\mathrm{Ni}$

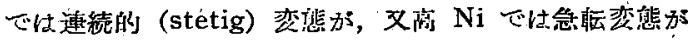
起るためと説明している. 而してその場合の $\gamma$ - $\boldsymbol{a}$ 変態

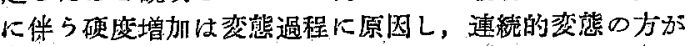

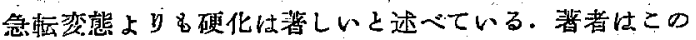

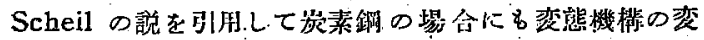
化があり，その影響が前述の国溶刿素に上る硬化と垂つ て 0.8\% C 附近で最离硬度を現わすのではないかと考 えている: (田中良平)

セミキルド鋼板の脆化温度に及ぼす熱処理の影 響 (R. H. Frazier, F: W. Boulger, C, H. Lorig: Journal of Metals, 7 (1955) 2-I , 323

平炬製銅せ $30.25 \% \mathrm{C}, 0.49 \% \mathrm{Mn}, 0.011 \%, \mathrm{P}$, $0.045 \% \mathrm{~S}, 0.04 \% \mathrm{Si}, 0.004 \% \mathrm{~N}$ の組成の七ミキル ド銓の厚さ $3 / 4$ インチの整間圧延板を $816^{\circ} \mathrm{C}$ 乃至1038 ${ }^{\circ} \mathrm{C}$ の温度に 1 h 加䓡後, 種々の冷却速度で济却し, そ れ等のフェライト絬晶灶の大きさ及びバーライトの分布

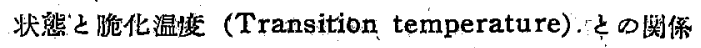
を求めた。脆化温度の诀定には Navy tear test とシ

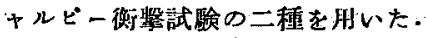

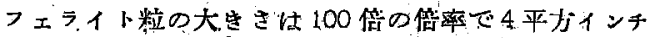

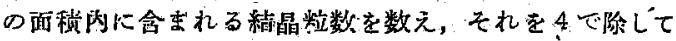
1 平方インチすたりの跡晶粒数で示した.バーライトの

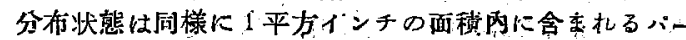
ライトの斑片の数で示した。

フェライト粒の大きさとパーライト片の密度纯，試料

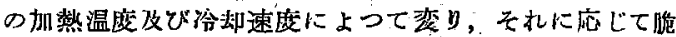
化温度变る。脆化温度山上述の2 程の決定法の間には 相罢があり，

(1) Navy tear test の場会に结脆化温度标つェ イト数の犬さのみの函数でハーラ゙ィト片密度には奥関係 である.フェ7ィト粒数方 12個/平方インチ(100倍率) だけ多くなる、脆化温度は的 0 ○ $55^{\circ} \mathrm{C}$ だ低くなる。

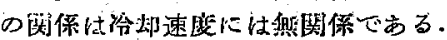

（2）シャルビー街撃試験の場合には脆化温度はつ土

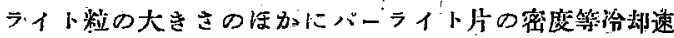

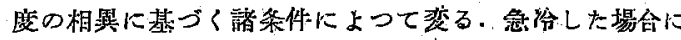
は脆化温度は主としてフェライト粒の大き令の数であ り，ASTM-結晶粒番号が 1 だけ與ると脆化温度は䄪 $16 \cdot 7^{\circ} \mathrm{C}$ だけ変る.（阿部）

クロム鋼及びモリブデン鋼の焼戻脆性 (G. Bhat, J. F. Libsch; Journal of Metals, 7 (1955) 2-II; 330)

$0.45 \% \mathrm{C}, \quad 0.77 \% \mathrm{Mn}, 0.35 \% \mathrm{Si}, 0.72 \% \mathrm{Cr} \odot$ AISI-5140 銅之, $0.48 \% \mathrm{C}, 0.83 \% \mathrm{Mn}, 0.28 \% \mathrm{Si}$, $0.14 \% \mathrm{Ni}, 0.13 \% \mathrm{Cr}, 0.25 \%$ Mo $\infty$ AISI-4047. を先づ $680^{\circ} \mathrm{CK5}$ 秒保持した後急给し, 次に $425^{\circ} \sim$

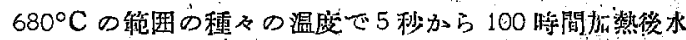

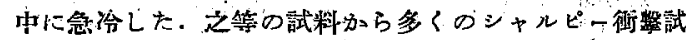
殿片を切り取り種々の温度で術整試験を行ひ脆化温度を 沃定した.

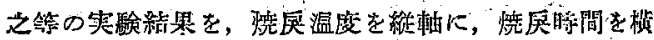
軸にとり，脆化温度一定の多くの的線て表した。仗を 等脆化温度协線一(Isoembrittlement curve) と言ふ..)

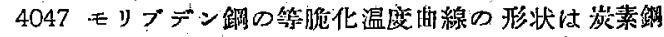

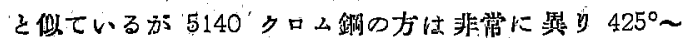
$540^{\circ} \mathrm{C}$ \& $680^{\circ} \mathrm{C}$ 㨁下の二つの温度籁围で脆性が認めら औ了.

一般にクロムを合有すると, $425^{\circ} \sim 540^{\circ} \mathrm{C}$ の温度筑焑 で燎杘す時の脆化を著しく炟長すると言える。例えば上

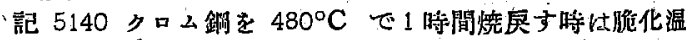
度往約 $13^{\circ} \mathrm{C}$ 『゙ある.

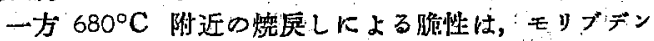

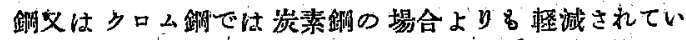
3.

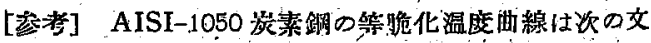

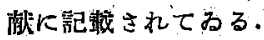

J. F. Libsch, A. E. Powers, G. Bhat; Trans. A.S.M., 44 (19.52), 1058, (阿部) : 